\title{
Factors hindering Indonesian lecturers from publishing articles in reputable international journals
}

\author{
Safnil Arsyad \\ safnil@unib.ac.id \\ English Education Study Program, Languages and Arts Department, \\ Teacher Training and Education Faculty, Universitas Bengkulu, Indonesia \\ Jl. WR Supratman Kandang Limun Bengkulu 38371, Indonesia \\ Bambang Kaswanti Purwo \\ bkaswanti@atmajaya.ac.id \\ Department of English Education, Faculty of Language and Education, \\ Universitas Katolik Atma Jaya Jakarta, Indonesia \\ Jl. Jend. Sudirman Karet Semanggi Setiabudi Jakarta 12930, Indonesia

\section{Katharina Endriati Sukamto} \\ katharina.sukamto@gmail.com \\ Department of English Education, Faculty of Language and Education, \\ Universitas Katolik Atma Jaya Jakarta, Indonesia \\ Jl. Jend. Sudirman Karet Semanggi Setiabudi Jakarta 12930, Indonesia

\section{Zifirdaus Adnan} \\ zadnan@une.edu.au \\ Department of Languages, University of New England, Armidale, Australia \\ Armidale NSW 2351, New South Wales, Australia
}

\begin{abstract}
The purpose of this study is to investigate the possible factors inhibiting the university lecturers or professors in Indonesia from publishing their research results in reputable international journals in English. The research used a mixed (quantitative and qualitative) method, employing a national survey and indepth interviews with selected lecturers and researchers in five different universities in Indonesia (i.e., Bengkulu University, Padang State University, Makasar State University, Unika Atma Jaya University and Mataram
\end{abstract}


Safnil Arsyad, Bambang Kuswanti Purwo, Katharina Endriati Sukamto, Zifirdaus Adnan

University). The results show that three main factors have hindered the lecturers from submitting their articles to reputable international journals: lack of self-confidence on the quality of their own research and article, finding it very difficult and very time consuming to prepare an article in English and no adequate reward for those who can successfully publish in reputable international journals. However, the majority of them have a positive attitude toward international journal publication for their own benefits or for the sake of their institution.

Keywords: international journal publication; academic and non-academic problems; reputable international journal

How to cite this paper: Arsyad, S., Purwo, B. K., Sukamto, K. E., \& Adnan, Z. (2019). Factors hindering Indonesian lecturers from publishing articles in reputable international journals. Journal on English as a Foreign Language, 9(1), 42-70. doi:http://dx.doi.org/10.23971 hefl.v9i1.982

DOI: http://dx.doi.org/10.23971 ßefl.v9i1.982

The efforts of the government to motivate and facilitate Indonesian academics to publish their research results in international journals have been able to increase Indonesian academic publications in reputable or indexed international journals. Data from Kemenristekdikti (2016) show that Indonesian academic publications from 2010 to 2016 experienced a significant increase although when compared to academic publications from neighboring countries such as Singapore, Malaysia and Thailand, they were still far fewer in number. According to data from the Ministry of Research, Technology and Higher Education, the number of Indonesian academic publications in international journals indexed by Scopus and the Web of Science has significantly increased from year to year and is higher than the number of publications from the Philippines. This increase is very encouraging because the general assumption is that the mastery of English by Indonesian academics is less than that of the Filipino scholars because in Indonesia English is a foreign language while in the Philippines it is a second language. This means mastering English is not a significant obstacle for Indonesian academics to publish in international English-language journals.

The data from Kemenristekdikti (2016) also show that Indonesian academic publications are mostly written by faculty members from the fields of science, technology, health and medicine such as Engineering (15.14\%), Medicine $(10.64 \%)$, Computer Science $(10.2 \%)$, Agriculture and Biological 
Safnil Arsyad, Bambang Kuswanti Purwo, Katharina Endriati Sukamto, Zifirdaus Adnan

Sciences (9.57\%), Physics and Astronomy (5.39\%), while publications from scholars in the fields of Social Sciences including Applied Linguistics and Language Education is only $(4.74 \%)$ and in the fields of Arts and Humanities, including Linguistics, is only $(0.91 \%)$. This implies that very few Indonesian academics in the fields of social sciences and humanities have successfully published reputable international journals compared to academics from the fields of science, technology, medicine and health. Thus, unlike those in the fields of science and technology and health and medicine, Indonesian scholars in social sciences and humanities may have faced more serious problems or obstacles to publish their research results in reputable international journals.

One of the possible causes of the low publication rate in international journals by lecturers in Social Sciences and Humanities is poor mastery of English so that they find it difficult to use references in online English-language journals or write articles in English correctly and appropriately as is expected by international journal readers. Another possible cause is that Indonesian academics are not familiar with the standard rhetorical style of each section of the English language journal articles as described by Swales (2004), and the differences and similarities in the rhetorical style of scientific articles in Indonesian and English as found by Safnil (2003), Mirahayuni (2002), Adnan (2009), Arsyad et al., (2016) and Arsyad and Arono (2016). The efforts to find the main cause of the low reputable international journal publication by Indonesian academics in the field of social sciences and humanities has encouraged researchers to conduct studies both from linguistic and nonlinguistic perspectives.

The possible different rhetorical styles of research articles (RA) in Indonesian and English have led to direct and indirect comparative research between Indonesian RAs written by Indonesian writers and those in English written by international authors. These studies were conducted by Safnil (2003), Adnan (2009), Arsyad (2013a), Arsyad (2013b) and Arsyad and Arono (2016). The purpose of these studies was to find out how the rhetorical style, citation style and linguistic features of RAs written in Indonesian by Indonesian writers in certain fields of discipline are different from or similar to those written in English by international authors. The results of these studies are very useful for academic writing purposes; that is to teach Indonesian authors to write RAs in English for international journal publication.

Safnil (2003) for example, found that the rhetorical style of the introduction section of Indonesian RAs in social science and humanities is different from $t$ that in English as in the CARS (creating a research space) model suggested by Swales (2004). Therefore, Safnil (2003) proposed a model of Journal on English as a Foreign Language, 9(1), $42-70$

Copyright $\odot 2019$ by JEFL, p-ISSN 2088-1657; e-ISSN 2502-6615 
rhetorical patterns that is more suitable to accommodate the communicative units contained in the Indonesian RA introduction section in the field of social sciences and humanities, which he called the problem justifying project (PJP) model. Unlike CARS, the PJP model has four Moves and each Move has more Steps compared to that in the CARS model. According to Safnil (2003), the PJP model is better in accommodating the various communicative units found in the introduction section of the Indonesian language RA than the CARS model. Safnil (2003) further explained that the addition of Move is specifically found in Move 1 (establishing shared background knowledge with readers) that is not included in the CARS model. Move 1 in the PJP model, according to Safnil (2003), is to accommodate the Indonesian writer's strategy of anticipating journal readers from different fields of discipline. Rifai (2016) claims that, unlike in English RAs, the aim of the introduction section in Indonesian RAs is to present a rational reason for conducting a study, to guide readers in reading the entire contents of the article, to announce the contribution of research results to existing knowledge, and to help solve practical problems found in society.

Adnan (2009) analyzed the rhetorical structure of the RA introduction section in the field of education written by Indonesian speakers using the CARS model from Swales (2004). He found that out of twenty-one Indonesian RA introductions in his research corpus, none of them matched the rhetorical style of an English RA introduction as in the CARS model of Swales (2004). The main difference, according to Adnan, is Move 1 (establishing a territory) where the majority of Indonesian writers discuss the importance of their research topic by referring to practical problems experienced by common people or government rather than by the relevant scientific discourse community. In addition, none of the Indonesian writers base their research projects by pointing to gaps or niches in the results or findings of relevant previous research as in Move 2 in the CARS model. Adnan proposed an ideal problem solution (IPS) which is a modification of the CARS model to capture the rhetorical style of Indonesian RA introductions, especially in the education discipline.

Studies by Arsyad et al., (2016) and Arsyad and Arono (2016) focused more on the analysis of the rhetorical patterns and linguistic features of the Indonesian RA introductions in the fields of social sciences and humanities. The results of their study support the findings of previous studies showing differences between the rhetorical style of Indonesian RA introductions and those in English RAs. The difference, according to Arsyad and Arono (2016) is that in contrast to English RAs, Indonesian authors: 1) consider preparing readers to read the RA as important; 2) tend to support the importance of the topic or title of their research with personal reasons and by referring to 
Safnil Arsyad, Bambang Kuswanti Purwo, Katharina Endriati Sukamto, Zifirdaus Adnan

previous research; and 3) tend to support the importance of their research activities in a subjective and personal manner. The results of this study are very important especially to find out how Indonesian authors should modify their research articles when writing them in English to be published in reputable international journals.

The rhetorical style of other parts of Indonesian RAs (i.e., abstract, research methodology and results and discussion) has also been examined by discourse analysts such as Arsyad (2013a) and Arsyad (2013b). Arsyad (2013a) examined the discussion section of 47 Indonesian RAs in the fields of social sciences and humanities published in university-based journals. Using the eight-move model (background of information, statement of results, (un) expected outcomes, reference to previous research, explanation, deduction and hypothesis and recommendation') from Swales (2004, p. 172), Arsyad (2013a) found that the eight Move model is quite effective in uncovering the communicative unit contained in the Indonesian RA discussions but there are differences between the Indonesian and English RA discussion sections. These differences include the fact that unlike English RA discussions, Move 4 (reference to previous research findings) is rarely found in Indonesian RA discussions. According to Arsyad (2013b), this difference is partly due to the different style of RA writing guidelines in Indonesian and in English.

The linguistic studies on RAs in English or Indonesian by Indonesian authors can partly answer the question of why Indonesian authors in social sciences and humanities are unable or unwilling to publish their research results in international journals. Some of the problems may not deal with the linguistic aspects of journal article writing but with the academic atmosphere existing on campus, such as incentives for publication, the lecturers' workload, their perception and confidence in writing and publishing RAs in international journals. Therefore, studies should be done on the non-linguistic aspects of academic writing experienced by the Indonesian authors.

The non-linguistic studies on international journal publication by Indonesian authors so far have concentrated on major areas, namely obstacles related to policy and regulations, funding, broad attitude toward research, and policy and practice at universities. Studies on policy and regulations examine how government policy and regulation hinder research activities and discourage academics from doing research. Study by Nielsen (2010), for example, looked at policies and regulations in economically emerging countries similar to Indonesia such as Brazil, Malaysia and Singapore and compare them with Indonesia. They found that funding for research in Indonesian is too small and much lower than the ideal amount, only $0.08 \%$ of the National Domestic

Journal on English as a Foreign Language, 9(1), $42-70$

Copyright $\odot 2019$ by JEFL, p-ISSN 2088-1657; e-ISSN 2502-6615 
Safnil Arsyad, Bambang Kuswanti Purwo, Katharina Endriati Sukamto, Zifirdaus Adnan

Bruto (NDB), while the ideal standard is around $1 \%$. This amount makes it difficult for researchers to obtain a decent amount of funding to do serious research. The study also found that regulation in Indonesia is over restrictive thereby making it very difficult to obtain the already small amount of funding, and to produce reports after the research is conducted. Meeting the requirements and expense of the regulations makes producing quality articles and publishing them difficult. There is also an issue of lack of pro-research leadership from the top leaders.

Similar findings were also made by McCarthy and Rustam (2010), who examined factors affecting the development of social sciences. They found issues at three levels, macro, meso (middle), and micro (individual). They suggested that the Government of Indonesia had no national framework for funding and development of high quality research, and there was no incentive to develop one's own research. They also found a funding issue: the low salary of academics drives them to do a lot more non-research activities to earn more money quickly to supplement their income, with consultant and teaching jobs outside their own campus. Other issues include no long-term funding for research centers, and at an individual level, there is no job security for research jobs. Karetji (2010) who looked at a broad overview of the knowledge sector in Indonesia, found another issue regarding funding; that is government bias towards technology and engineering sectors at the expense of other fields. He also found the absence of a clear career path for researchers, and a gap between research and government policy.

As all the above studies point to the same issue of lack of research funding, Brodjonegoro and Greene (2012) also examined the issue and found difficulties in getting funding and rigidity in the reporting system as serious problems inhibiting serious research. Therefore, they made a case for the establishment of Dana Ilmu Pengetahuan Indonesia (DIPI) or Indonesian Research Fund, which has now been supported by the government. However, it is yet to be seen how effective this funding scheme is. The fact is although the issue of poor funding has been acknowledged by the Minister of Research and Higher Education and there is a promise to increase it, funding for the 2017 financial year has in fact been reduced. Apparently, other priorities are still higher than research.

More recently, two studies are being conducted respectively by the University of Indonesia and the Centre for Innovation Policy and Governance sponsored by Global Development Network. One is a study on reform of research in Indonesia. This study examines factors inhibiting research at macro, meso (middle) and micro (individual) levels focusing on social sciences. It 
examines seven case studies in different regions in Indonesia including Aceh and Papua. At the macro level, this study examines government policy and regulations; at the middle level, how universities interpret these policy and regulations to develop their own policy and regulations, and at the micro level, how these middle level policy and regulations affect individual researchers at the universities. The other study is conducted by the Indonesian Science Academy (AIPI) and sponsored by an Australian-Indonesian supported project called Knowledge Sector Initiative abbreviated as KSI (Nugroho, Budiati, \& Ruhanawati, 2016). This study is called 'Buku Putih Pendidikan Tinggi' (White Book of Higher Education), which concentrates on the issue of 'monodisciplinary' or 'linearity' adopted in Indonesia versus a 'multi-disciplinary' approach to research. No publications of these studies have been found, but according to Nugroho et al. (2016), the consultative group of these two studies, the studies should consider not only conceptual and philosophical issues, but also recommend an appropriate intervention to change the inhibiting factors. Amongst the issues to be investigated are the issues already identified in the previous studies, for example, the disharmony between research activities, researchers and contexts, the very small amount of funding, the lack of attention to the 'National Research Agenda', the lack of a career path for researchers, and the lower salary for researchers compared to lecturers.

The aforementioned projects investigated factors inhibiting research at universities partnering with Knowledge Sector Initiative i.e. Universitas Indonesia (The University of Indonesia), Gadjah Mada University (UGM), Universitas Islam Negeri (UIN) Jakarta, and the Atma Jaya University of Jakarta. As described above, all of these studies investigated structural and environmental problems inhibiting research at those universities. While these studies provide major contributions to understanding problems of low research outputs, there is still much to be done such as the actual problems individual researchers face when trying to publish their research. The urgent question is why these studies have not helped increase Indonesian international journal publication when the amount of research has been increased, some funded by the government or their universities. In the past, there were many good quality research projects, but the low number of articles published in international journals suggests that they were not published or published only in local or national journals. It is difficult to ascertain how many government-funded research projects have not been published in international journals, but the statement made by the Minister for Research, Technology and Higher Education, that he will chase the academics who have promised to publish from their government funded research projects to keep their promise, seems to imply that the number is not negligible. 
The main reasons according to Nugroho et al. (2016) are the limited amount of incentive provided to publish research results and the poor ability of the researchers to write these in English in order to publish them in an international journal. Consequently, the only outcome of the project has been reports to the fund provider. However, this is certainly not the only reason for the university lecturers especially from Linguistics, Applied Linguistics, and Language Education for not publishing their research results in reputable journals; there must be other possible causes such as lack of relevant references, poor research quality, confidence in writing articles in English and limited information about reputable international journals. This is the main motivation for this study; that is to find out comprehensive information on the possible causes why very few Indonesian scholars in Linguistics, Applied Linguistics, and Language Education successfully publish their research findings in reputable international journals. Thus, this study is aimed at answering the following questions: 1) what factors have hindered Indonesian lecturers in linguistics, applied linguistics, and language education from publishing their research results in reputable international journals?; 2) what are lecturers' attitudes toward publishing their research results in reputable international journals?; and 3) what are some necessary steps which should be taken to help the lecturers successfully publish their research results in reputable international journals?

\section{METHOD}

To answer the research questions, this study employed a mixed method, simple quantitative and with emphasis on qualitative following Creswell (2009). The simple quantitative method was employed to find out the level of agreement or disagreement among the population in regard to a particular statement. For example, the higher the percentage of population selecting 'strongly agree', the higher the support for the statement is. Conversely, the lower the percentage of the population the lower the level of support for the statement is. Findings from this method were examined through interviews with $5 \%$ of the population selected randomly.

\section{Quantitative Method}

The study employed a multi-purpose sampling method, in which the population members were selected on the basis of the purposes already specified. Basically, they are active researchers who have had research project reports, which have not been publicized; they should be from the disciplines already specified, namely linguistics, applied linguistics and language 
Safnil Arsyad, Bambang Kuswanti Purwo, Katharina Endriati Sukamto, Zifirdaus Adnan

education. The universities were selected based on some geographical representation and feasibility considerations. The number of researchers who met these criteria may be limited and different from one university to another.

Based on these criteria, the population was active researchers, whose names were collected from research centers of the 5 universities in Indonesia: Bengkulu University, Universitas Katolik Atma Jaya Jakarta, Makasar State University, Padang State University and Mataram University in the three disciplines mentioned earlier. A minimum of 15 researchers from each of these universities were selected to complete a survey developed based on the research questions.

The data were collected through a survey with close and open question questionnaire (see Appendix 1 for the questionnaire). The close questions were in the form of multiple choice and the open questions were in the form of written comments. These survey questions included questions such as whether they have a research project report that has not been published, and if they were willing to submit the reports to the Team for assessment. And, if their reports were selected, whether they would be willing to be involved in a mentoring process and convert their report into a RA that meets the general standards of international journals.

\section{Qualitative Method}

The open comments from the survey were analyzed qualitatively. The purpose was to find the deepest meaning possible in terms of the main reasons why the researchers have not publicized their research reports. A main reason means a reason, which is frequently presented by the respondents with logical and convincing explanation. In this case, three stages of analysis were conducted. The first was the tagging of the data based on recurring themes. The second was the calculation of the recurring themes, and finally, making generalizations and interpreting the results of the first and the second stages of analysis. This analysis was also conducted to find out the extent to which the findings in the quantitative analysis are fundamentally supported by the open comments of the respondents.

\section{Respondents}

The respondents for this study were chosen from five different universities as mentioned above. Twenty respondents were intentionally chosen from each university to make a total of 100 respondents who received a set questionnaire. However, a different number of respondents from each 
Safnil Arsyad, Bambang Kuswanti Purwo, Katharina Endriati Sukamto, Zifirdaus Adnan

university returned the filled-in questionnaire. See Table 1 for distribution of the respondents who returned the questionnaire.

Table 1. The Distribution of Respondents who returned the Questionnaire

\begin{tabular}{clccc}
\hline No. & \multicolumn{1}{c}{ University } & Code & $\begin{array}{c}\text { Number of } \\
\text { Respondents }\end{array}$ & $\%$ \\
\hline 1. & Bengkulu University & UNIB & 12 & 16.7 \\
\hline 2. & Makasar State University & UNM & 19 & 26.4 \\
\hline 3. & Padang State University & UNP & 14 & 19.4 \\
\hline 4. & Mataram University & UNRAM & 17 & 23.6 \\
\hline 5. & Universitas Katolik Atma Jaya & UKA & 10 & 13.9 \\
\hline \multicolumn{7}{c}{ Total } & & 72 & 100 \\
\hline
\end{tabular}

As shown in Table 1, the total number of respondents who filled in and returned the questionnaire is 72 out of $100(72 \%)$ who were given it. Then at least $5 \%$ of the respondents were selected randomly and interviewed in order to get more information from the lecturers on the same topics. The list of questions for the interviews is attached in Appendix 2.

\section{FINDINGS}

The first groups of questions in the questionnaire are not addressed in the research questions and are about respondents' research and publication lives in campus in general. The data show the following information: a) few $(23.9 \%)$ respondents who have ever received research funding assistance from the central government or from other funding sources submitted articles to reputable international journals, while most respondents $(76.1 \%)$ have never received research funding assistance; b.) most respondents (74.6\%) have published articles in local or national journals; c.) few (34.3\%) respondents have published in accredited national journals such as Indonesian Linguistics, Humanities, Humanities, Humanists, Education and Culture, Linguistics, Discourse, Learning Journals, Educational Forms; d.) very few (17.9\%) of respondents have published in reputable/indexed international journals such as The New Educational Review, Eurasian Journal of Educational Research, The Journal of Language Teaching and Learning, etc.; e.) few (23.9\%) respondents have never published at all; f.) only a small number (10.45\%) of respondents have published in accredited national journals or reputable/indexed international journals; g.) of the respondents who have not published in international journals, $65.7 \%$ are trying to prepare articles to be sent to international journals with Scopus index or Web of Science. 
From the interview results, most lecturers seem to be reluctant to publish in journals due to taxing administrative tasks coupled with the obligation to implement the Tridharma of Higher Education (i.e., teaching, conducting research and doing community service). One of the lecturers from UNRAM interestingly reported that '... most lecturers still think that they are teachers at college, so their main task is teaching not doing research and publishing the results in journals. They are reluctant to write scientific papers because they don't consider themselves as researchers but as teachers. Especially for lecturers from education faculties; it may be that such views are still strong. There are still lecturers whose priority is the number of teaching credits and experience, so that their opportunity to do research and publications is very limited.

\section{Factors Hindering Indonesian Lecturers from Publishing in Reputable International Journals}

The second group of questions addressed in the questionnaire is about factors which might have hindered the lecturers from publishing their research results in international journals. See Table 2 for the data in percentage.

Table 2. Hindering Factors for Publishing in Reputable International Journals

\begin{tabular}{lcccccc}
\hline $\begin{array}{l}\text { Reasons for not } \\
\text { publishing in reputable } \\
\text { international journals }\end{array}$ & $\begin{array}{c}\text { Do not } \\
\text { hinder } \\
(\%)\end{array}$ & $\begin{array}{c}\text { Hinder } \\
\text { a little } \\
\text { bit }(\%)\end{array}$ & $\begin{array}{c}\text { Hinder } \\
\text { enough } \\
(\%)\end{array}$ & $\begin{array}{c}\text { Hinder } \\
\text { very } \\
\text { much } \\
(\%)\end{array}$ & $\begin{array}{c}\text { The } \\
\text { hindering } \\
\text { factor is not } \\
\text { significant } \\
(\%)\end{array}$ & $\begin{array}{c}\text { N/A } \\
(\%)\end{array}$ \\
\hline $\begin{array}{l}\text { 1. Inadequate quality of } \\
\text { research }\end{array}$ & 41.8 & 13.4 & 23.9 & 3.0 & 1.5 & 16.4 \\
\hline $\begin{array}{l}\text { 2. Writing articles for } \\
\text { international journal } \\
\text { is too difficult (i.e., } \\
\text { there are many } \\
\text { requirements to meet) }\end{array}$ & 48.2 & 10.7 & 23.2 & 10.7 & 7.1 & 0.0 \\
\hline $\begin{array}{l}\text { 3. There is no incentive } \\
\text { for those who publish } \\
\text { in international }\end{array}$ & 53.6 & 12.5 & 21.4 & 8.9 & 3.6 & 0.0 \\
journals & & & & & & \\
\hline $\begin{array}{l}\text { 4. There is no financial } \\
\text { support to write an } \\
\text { article for } \\
\text { international journal }\end{array}$ & 50.0 & 12.5 & 19.6 & 10.7 & 7.1 & 0.0 \\
& & & & & & \\
\end{tabular}


Safnil Arsyad, Bambang Kuswanti Purwo, Katharina Endriati Sukamto, Zifirdaus Adnan

\begin{tabular}{|c|c|c|c|c|c|c|}
\hline $\begin{array}{l}\text { 5. I do not have enough } \\
\text { knowledge about } \\
\text { reputable } \\
\text { international journals }\end{array}$ & 43.3 & 9.0 & 19.4 & 9.0 & 1.5 & 17.9 \\
\hline $\begin{array}{l}\text { 6. I do not know the } \\
\text { format of } \\
\text { international journal } \\
\text { articles }\end{array}$ & 53.6 & 12.5 & 17.9 & 8.9 & 7.1 & 0.0 \\
\hline $\begin{array}{l}\text { 7. My ability in writing } \\
\text { in English is poor }\end{array}$ & 57.1 & 17.9 & 17.9 & 3.6 & 3.6 & 0.0 \\
\hline $\begin{array}{l}\text { 8. Lack of references } \\
\text { available at the } \\
\text { faculty and/or } \\
\text { university library }\end{array}$ & 51.8 & 14.3 & 14.3 & 8.9 & 10.7 & 0.0 \\
\hline $\begin{array}{l}\text { 9. I do not like } \\
\text { international journals } \\
\text { because it is a tool of } \\
\text { western countries to } \\
\text { control other } \\
\text { countries or new } \\
\text { forms of colonialism }\end{array}$ & 55.2 & 17.9 & 14.9 & 6.0 & 6.0 & 0.0 \\
\hline $\begin{array}{l}\text { 10. Fear of articles not } \\
\text { being accepted by } \\
\text { editors or reviewers } \\
\text { of international } \\
\text { journals }\end{array}$ & 29.9 & 20.9 & 31.3 & 11.9 & 6.0 & 0.0 \\
\hline $\begin{array}{l}\text { 11. I do not feel } \\
\text { confident on data } \\
\text { analysis ability which } \\
\text { results in poor } \\
\text { research articles }\end{array}$ & 25.4 & 26.9 & 31.3 & 9.0 & 7.5 & 0.0 \\
\hline $\begin{array}{l}\text { 12. I am afraid if the } \\
\text { article is not accepted } \\
\text { by the editor or } \\
\text { reviewer of } \\
\text { international journals }\end{array}$ & 43.3 & 19.4 & 20.9 & 7.5 & 9.0 & 0.0 \\
\hline $\begin{array}{l}\text { 13. I am not interested } \\
\text { in publishing in } \\
\text { international journals, } \\
\text { because they are not } \\
\text { financially attractive } \\
\text { while their demands } \\
\text { are high, especially } \\
\text { when rewards are }\end{array}$ & 55.2 & 19.4 & 16.4 & 6.0 & 3.0 & 0.0 \\
\hline
\end{tabular}

Journal on English as a Foreign Language, 9(1), 42-70

Copyright @ 2019 by JEFL, p-ISSN 2088-1657; e-ISSN 2502-6615 
Safnil Arsyad, Bambang Kuswanti Purwo, Katharina Endriati Sukamto, Zifirdaus Adnan

\begin{tabular}{lllllll}
\hline uncertain & & & & & \\
\hline $\begin{array}{l}\text { 14. I feel ashamed if the } \\
\text { article quality is too }\end{array}$ & 37.3 & 26.9 & 25.4 & 4.5 & 6.0 & 0.0 \\
low & & & & & & \\
\hline $\begin{array}{l}\text { 15. It is not necessary to } \\
\text { publish in }\end{array}$ & 62.7 & 17.9 & 10.4 & 6.0 & 3.0 & 0.0 \\
international journals; \\
publishing in national \\
journal is enough
\end{tabular}

As can be seen in Table 2, the majority of respondents $(37.3 \%-62.7 \%)$ reported that the reasons for not publishing in international journals as stated in the questionnaire did not prevent them from publishing in reputable international journals except item number 1 (in adequate quality of research), item number 2 (it is too difficult to write articles for international journal, i.e., there are many requirements to meet), item number 5 (do not have enough knowledge about reputable international journals), item number 10 (fear of articles not being accepted by editors or reviewers of international journals) and item number 11 (do not feel confident on data analysis ability which results in poor research articles). These items deal with the lecturers' perception about the quality of their own research and articles and about publishing in international journals.

The majority of respondents also reported that the top three reasons inhibiting them from writing an article for an international journal include: a) feeling ashamed if the quality of the article is too low, b) writing reputable journal articles is too difficult (for example, many requirements must be met), and c) there are no incentives available to those who publish in reputable international journals. This answer makes sense because all respondents in this study are lecturers. A lecturer has three main tasks called Tridharma and one component is doing field research. In addition there are two other tasks, namely teaching and community service. These last two tasks are very time consuming, for example preparing for college or training along with all the administrative work that follows. Research sometimes becomes neglected or conducted without careful planning. Although research can work, the constraints that arise are usually time and resources. Lecturers must be able to divide time between various priorities that are susceptible to very dynamic changes. For example, he must attend a seminar, supervise students or fill in study program accreditation forms that take up a lot of work time. Not to mention, the lecturers may have a family that must be taken care of or need extra attention. In writing articles for reputable international journals, extra dedication is needed. 
The respondents also reported in the interview that the determining problems in international journal publications are 1) the availability of inadequate international references in faculty and/or university libraries, 2) writing reputable journal articles is too difficult (for example, because many requirements must be met), 3) no financial help for writing articles for international journal publications, and 4) unawareness of the format of article writing that applies to international journals. These data imply that external factors become the main reasons for the lecturers not publishing in reputable international journals. These external factors include facilities (availability of references) and knowledge that can be accessed by respondents (financial assistance, writing format).

\section{Attitude towards Publishing in Reputable International Journals}

The third group of statements in the questionnaire is about lecturer's attitude on international journal publication. The data from the respondents are displayed in Table 3.

Table 3. Attitude towards Reputable International Journal Publication

\begin{tabular}{lcccccc}
\hline $\begin{array}{l}\text { Attitude towards } \\
\text { reputable international } \\
\text { journals }\end{array}$ & $\begin{array}{c}\text { Strongly } \\
\text { disagree } \\
(\%)\end{array}$ & $\begin{array}{c}\text { Disagree } \\
(\%)\end{array}$ & $\begin{array}{c}\text { Neutral } \\
(\%)\end{array}$ & $\begin{array}{c}\text { Agree } \\
(\%)\end{array}$ & $\begin{array}{c}\text { Strongly } \\
\text { agree } \\
(\%)\end{array}$ & $\begin{array}{c}\text { N/A } \\
(\%)\end{array}$ \\
\hline $\begin{array}{l}\text { 1. I do not have time to } \\
\text { write because too much }\end{array}$ & 4.5 & 20.9 & 13.4 & 32.8 & 28.4 & 0.0 \\
$\begin{array}{l}\text { work such as teaching, } \\
\text { administrative work and } \\
\text { conducting social service } \\
\text { activities or other tasks } \\
\text { in campus. }\end{array}$ & & & & & & \\
\hline $\begin{array}{l}\text { 2. If one can help, I will } \\
\text { work hard to write an } \\
\text { article for an }\end{array}$ & 3.0 & 3.0 & 7.5 & 31.3 & 53.7 & 1.5 \\
international journal & & & & & & \\
\hline
\end{tabular}

Table 3 shows that the majority of the lecturers reported that although they may be busy with academic work such as teaching, doing research and doing community service (Tridharma), and with administrative work such as writing annual plans and reports on their work performance, completing applications for a career pay raise, or helping their study program complete accreditation forms, they are willing to work hard in order to write articles to be submitted to an international journal if they receive help from someone. In 
addition, the lecturers seem to have a positive attitude towards publishing in reputable international journals. Their responses about advantages from publishing in reputable international journals are summarized in Table 4.

As shown in Table 4, the following benefits are perceived by most respondents $(46.3 \%-61.2 \%)$ if a lecturer has publications in reputable international journals: 1) credit points for career promotion, 2) credibility for institutions, 3) self-satisfaction/pride, and 4) personal credibility. Especially for cash incentives, some respondents (35.8\%) stated that they are quite influential. Other advantages according to the respondents can be divided into internal and external ones. Internal benefits include: 1) self-confidence as a scientist or lecturer, 2) extending networking with the scientific community, 3) socializing research findings, 4) increasing personal reputation, 5) to be an invited speaker in scientific meetings, 7) motivation for lecturers to focus more on the fields they are engaged in and develop them, 8) intellectual inheritance, 9) development and self-actualization. External benefits include: 1) help increase Indonesian publications, 2) assist study program accreditation, and 3) help increase the country's fame in the eyes of the international academic community. Thus, it can be inferred that the benefits that can be obtained by lecturers who have publications in reputable international journals are perceived as internal rather than external advantages.

Table 4: Advantages from Reputable International Journal Publication

\begin{tabular}{lccccc}
\hline $\begin{array}{l}\text { Advantages from } \\
\text { publishing in reputable } \\
\text { international journals }\end{array}$ & $\begin{array}{c}\text { Do not } \\
\text { affect at all } \\
(\%)\end{array}$ & $\begin{array}{c}\text { Affect a } \\
\text { little } \\
(\%)\end{array}$ & $\begin{array}{c}\text { Affect } \\
\text { enough (\%) }\end{array}$ & $\begin{array}{c}\text { Affect very } \\
\text { much but } \\
\text { not } \\
\text { determin- } \\
\text { ing }(\%)\end{array}$ & $\begin{array}{c}\text { Affect } \\
\text { the } \\
\text { most } \\
(\%)\end{array}$ \\
\hline $\begin{array}{l}\text { 1. For financial } \\
\text { incentive }\end{array}$ & 11.9 & 11.9 & 35.8 & 22.4 & 17.9 \\
\hline $\begin{array}{l}\text { 2. For personal } \\
\text { credibility }\end{array}$ & 3.0 & 9.0 & 14.9 & 26.9 & 46.3 \\
\hline $\begin{array}{l}\text { 3. For personal } \\
\text { satisfaction }\end{array}$ & 3.0 & 4.5 & 11.9 & 20.9 & 59.7 \\
\hline $\begin{array}{l}\text { 4. For credit points for } \\
\text { career promotion as a } \\
\text { government official }\end{array}$ & 3.0 & 1.5 & 11.9 & 22.4 & 61.2 \\
\hline $\begin{array}{l}\text { 5. For institution } \\
\text { credibility }\end{array}$ & 3.0 & 3.0 & 7.5 & 25.4 & 61.2 \\
\hline
\end{tabular}




\section{Efforts to Prepare Articles for Reputable International Journal Publication}

The respondents' opinions on necessary efforts to be taken to prepare articles to be acceptable for reputable or indexed international journal publication are shown in Table 5.

According to the majority of respondents (41.8\% - 59.7\%), the following efforts are considered effective to successfully publish in reputable international journals. These include: 1) studying the format and style of writing research articles in international journals (among others, through reading guide books of scientific work), 2) reading research articles published in international journals as much as possible, 3) confidently sending each research article to reputable international journals (although it may not be accepted), 4) frequently writing articles (although in Indonesian) to be published in national accredited journals, 5) frequently attending workshops on publications in reputable international journals, 6) requesting help from researchers who have successfully published their articles in reputable international journals.

Table 5. Necessary efforts to prepare articles for reputable international journal

\begin{tabular}{|c|c|c|c|c|c|}
\hline $\begin{array}{l}\text { The necessary efforts to } \\
\text { write articles for } \\
\text { international journals }\end{array}$ & $\begin{array}{c}\text { Not } \\
\text { effective } \\
(\%)\end{array}$ & $\begin{array}{l}\text { A little } \\
\text { bit } \\
\text { effective } \\
(\%)\end{array}$ & $\begin{array}{l}\text { Effective } \\
\text { enough } \\
(\%)\end{array}$ & $\begin{array}{c}\text { Very } \\
\text { effective but } \\
\text { not } \\
\text { determining } \\
(\%)\end{array}$ & $\begin{array}{l}\text { The } \\
\text { most } \\
\text { effective } \\
(\%)\end{array}$ \\
\hline $\begin{array}{l}\text { 1. Improving English } \\
\text { ability }\end{array}$ & 17.9 & 3.0 & 16.4 & 32.8 & 29.9 \\
\hline $\begin{array}{l}\text { 2. Studying the format } \\
\text { and writing style of } \\
\text { international journal } \\
\text { articles (i.e., via guide } \\
\text { books on academic } \\
\text { writing) }\end{array}$ & 7.5 & 4.5 & 7.5 & 25.4 & 55.2 \\
\hline $\begin{array}{l}\text { 3. Writing articles in } \\
\text { Indonesian and then } \\
\text { asking for help to } \\
\text { translate it into } \\
\text { English }\end{array}$ & 29.9 & 13.4 & 19.4 & 14.9 & 22.4 \\
\hline $\begin{array}{l}\text { 4. Reading published } \\
\text { articles in reputable } \\
\text { international journals } \\
\text { as many as possible }\end{array}$ & 6.0 & 0.0 & 11.9 & 29.9 & 52.2 \\
\hline
\end{tabular}

Journal on English as a Foreign Language, 9(1), 42-70

Copyright (C 2019 by JEFL, p-ISSN 2088-1657; e-ISSN 2502-6615 
Safnil Arsyad, Bambang Kuswanti Purwo, Katharina Endriati Sukamto, Zifirdaus Adnan

\begin{tabular}{|c|c|c|c|c|c|}
\hline $\begin{array}{l}\text { 5. Confidently sending } \\
\text { every research article } \\
\text { to a reputable } \\
\text { international journal } \\
\text { regarding its quality }\end{array}$ & 6.0 & 0.0 & 17.9 & 26.9 & 49.3 \\
\hline $\begin{array}{l}\text { 6. Writing article } \\
\text { frequently although } \\
\text { in Indonesian for } \\
\text { national accreditted } \\
\text { journal publication }\end{array}$ & 7.5 & 4.5 & 23.9 & 20.9 & 43.3 \\
\hline $\begin{array}{l}\text { 7. Frequently attending } \\
\text { workshop on } \\
\text { reputable } \\
\text { international journal } \\
\text { publication }\end{array}$ & 7.5 & 3.0 & 22.4 & 25.4 & 41.8 \\
\hline $\begin{array}{l}\text { 8. Asking for mentoring } \\
\text { with experienced } \\
\text { lecturers who have } \\
\text { successfully } \\
\text { published in } \\
\text { reputable } \\
\text { international journals }\end{array}$ & 7.5 & 0.0 & 11.9 & 20.9 & 59.7 \\
\hline
\end{tabular}

Although the majority of respondents reported that they tried to publish in indexed international journals, some of them $(32.8 \%)$ stated that improving their English skills was very effective although not decisive. In addition, some $(29.9 \%)$ also thought that writing articles in Indonesian, then asking for the help to translate them into English was also an effective effort. Respondents also have several proposals to encourage publications in reputable international journals: 1) conduct routine research, 2) start writing in local-nationalinternational journals, 3) write articles with other researchers who have published their articles in reputable international journals, and 4) establishing a university/faculty review team.

\section{DISCUSSION}

The first question addressed in this study is what factors have hindered Indonesian lecturers in Linguistics and Language Education from publishing their research results in reputable international journals. The data show that from 15 questions asked to the respondents, there are mainly two factors which seem to hinder them from publishing in reputable international journals; these are their perception on the poor quality of their own research and articles and 
Safnil Arsyad, Bambang Kuswanti Purwo, Katharina Endriati Sukamto, Zifirdaus Adnan

their fear for their manuscripts to be rejected by journal editors and/or reviewers. Belcher (2009) puts it rightly that when you write you will be rejected; the fear of rejection by international journals especially high-ranking ones is experienced by every author, even experienced ones. In other words, writing articles for international journals is very hard work especially for new authors; however, according to Belcher (2009), the work as hard as it is, if it is frequently done it will be easier. Similarly, Day (2007) suggests that fear of being rejected or turned down by a journal is the most frequent reason for faculty members not to publish in journals. However, according to Day (2007) it is only an excuse by the lecturers for not preparing their work seriously and well; if authors have done their best to do research and write a manuscript, then there is nothing to fear at all. This is because, according to Belcher (2009), an article rejected by a journal will be accepted by another journal after several revisions. Revising and correcting manuscripts following suggestions and corrections from journal editors and/or reviewers becomes an important learning process, especially for novice authors to develop their academic writing competence and ability.

A similar finding was reported by Feyera, Atelaw, Hassen, and Fufa (2017) when they investigated factors regarded as obstacles by faculty members in Jigjiga University in Ethiopia dealing with publication productivity. They found that among the socio-demographic and institutional variables considered significant problems by the university lecturers for publication are 'academic qualification, rank, discipline, track records on research grant winning, theses supervision as well as attending academic conferences and research related trainings' (Feyera, et al., 2017, p. 567). Thus, problems in journal publication are complex; there are many factors contributing to the success and failure of publishing in reputable international journals and therefore, it should be viewed and solved from several different angles.

The second research question in this study concerns lecturers' attitude toward publishing their research results in reputable international journals. The findings reveal that the majority of the lecturers have a positive attitude towards international journal publication. If they get help, most of them are willing and ready to write articles for international journals although they may be busy with other academic and administrative work. This is because they perceive and agree with the direct or indirect advantages of publishing in international journals, either for their own benefit or for that of their institution. Day (2007) states correctly, 'Ideas are cheap. No one succeeds because they have good ideas. No single person ever became famous, rich or even promoted on the strength of an idea. It was because they did something with their idea that 
Safnil Arsyad, Bambang Kuswanti Purwo, Katharina Endriati Sukamto, Zifirdaus Adnan

they reached their desired goal' (Day, 2007, p.11). The lecturers have already been aware of the various advantages of publishing in reputable journals and if they get help by experienced authors or financial support by their institution, they are ready to work hard to do research and write articles for reputable international journals although it is in English. This is because, according to Cargill and Burgess (2016), English has been dominant as the language of publication in the world.

The last question addressed in this study is what steps are needed to help the lecturers successfully publish their research results in reputable international journals. The results show that two main types of activities are considered necessary: becoming familiar with the journal article format and writing style and developing writing ability through actual writing practices and attending seminar and workshops. This is in line with Feyera et al., (2017) when they suggest that in order to increase publication of the faculty members of a particular institution, several efforts must be undertaken. These are, among other things, appreciation, rewards, training, financial support and a good atmosphere. A similar recommendation has been made by Olszewska and Lock (2016) when they found in their study that the main factor affecting the success of academic writing among faculty members is group or collaborative writing with clear purpose and committed members and institutional support. According to Olszewska and Lock (2016), the group members will develop their academic writing competence and skills through sharing their work with others, peer correcting and editing and group discussion during the writing processes. The challenge is, as Olszewska and Lock (2016) claim further, how to keep their high motivation to do research and write articles together. This is where the institution can play an important role by supporting the lecturers financially and morally to publish their research results in reputable international journals. Publication should be at the center of academic tasks and the responsibility of every faculty member.

\section{CONCLUSION}

From the many different reasons reported by the respondents in this study, there are three main ones that hinder lecturers from publishing their research findings in reputable international journals. The first one is their feeling of inferiority about the quality of their own research and articles. Secondly, they think that publishing a research article in a reputable international journal is quite tough and time-consuming. Lastly, if their article can be published, there is no incentive given to them. However, the majority of the respondents have a positive attitude toward international journal publication for their own benefit and that of their institution. Publishing in Journal on English as a Foreign Language, 9(1), 42-70

Copyright $\odot 2019$ by JEFL, p-ISSN 2088-1657; e-ISSN 2502-6615 
Safnil Arsyad, Bambang Kuswanti Purwo, Katharina Endriati Sukamto, Zifirdaus Adnan

reputable international journals will be possible if they put a lot of effort into the following: 1) paying attention to the format and style of writing research articles in such journals (among others, by reading guide books of scientific work), 2) reading research articles published in them, 3) sending research articles to reputable ones (although chances to be accepted are small), 4) frequently writing articles (even in Indonesian) to be published in national accredited journals, 5) attending workshops on publishing in reputable international journals, and 6) requesting assistance from researchers who have successfully published their articles in such journals.

It is suggested that in order to be successful in reputable international journal publication university lecturers in Linguistics, Applied Linguistics and Language Education must have both internal and external motivation. Internal motivation is necessary for several reasons: 1 ) to learn and be familiar with the targeted journal article format and writing style; 2) to frequently practice writing articles collaboratively with the help of a mentor or experienced writer and submitting $t$ them to a reputable international journal; 3 ) to always revise their article drafts following the suggestions and corrections from the journal editors and/or reviewers' and 4) to frequently attend seminars and workshops on academic writing, especially ones aimed at writing articles for international journals. External motivation may come from an institution's leaders. It is very important in order to strengthen lecturers' own internal motivation so that they can sustain their hard work to produce high quality articles for reputable international journal publication.

\section{ACKNOWLEDGEMENTS}

This research was supported by the Ministry of Research, Technology and Higher Education through the Directorate of Research and Community Services (DRPM), International Research Collaboration and Scientific Publication Scheme 2018. Therefore, we would like to express our sincere gratitude. Any opinions, findings, and conclusions or recommendations expressed in this article are those of the authors and do not necessarily reflect the views of the respected ministry.

\section{REFERENCES}

Adnan, Z. (2009). Some potential problems for research articles written by Indonesian academics when submitted to international English language journals. The Asian EFL Journal Quarterly, 11(1), 107-125. 
Arsyad, S. (2013a). A genre-based analysis on discussion section of research articles in Indonesian written by Indonesian speakers. International Journal of Linguistics, 5(4), 50-70.

Arsyad, S. (2013b). A genre-based analysis on the introduction of research articles written by Indonesian academics. TEFLIN Journal, 24(2), 180-194.

Arsyad, S., \& Arono (2016). Potential problematic rhetorical style transfer from first language to foreign language: A case of Indonesian authors writing research article introductions in English. Journal of Multicultural Discourses, 11(3), 315-330.

Arsyad, S., Arono, Syaputra, J., Susilawati, Susanti, R., \& Musarofah. (2016). Tipe dan fungsi pengutipan di bagian pendahuluan artikel jurnal berbahasa Indonesia [Type and functions of citation in introduction section of Indonesian articles]. Linguistik Indonesia, 34(2), 163-178.

Belcher, W. L. (2009). Writing your journal article in 12 weeks: A guide to academic publishing success. Thousand Oaks, CA: Sage Publications Inc.

Brodjonegoro, S. S., \& Greene, M. P. (2012). Creating an Indonesian research fund. Retrieved from http://www.aipi.or.id/admin/assets/pdf/ publication/indonesiansciencefundpdf_4Q91Q.pdf

Cargill, M., \& Burgess, S. (2016). Unpacking English for research publication purposes [ERPP] and the intersecting roles of those who research, teach and edit it. In M. Cargill and S. Burgess (Eds.), Publishing research in English as an additional language: Practices, pathways and potentials. Adelaide, Australia: The University of Adelaide Press.

Creswell, J. W. (2009). Research design: Qualitative, quantitative and mix method approaches. Los Angeles, CA: Sage.

Day, A. (2007). How to get research published in journals ( $2^{\text {nd }}$ ed.). Hamshire, TX: Gower Publishing Ltd.

Feyera, T., Atelaw, H., Hassen, N. A., \& Fufa, G. (2017). Publication productivity of academics in Jigiga university, Ethiopia. Education Research and Reviews, 12(9), 559-568.

Karetji, P. (2010). Overview of the Indonesian knowledge sector. Retrieved from http://dfat.gov.au/about-us/publications/Documents/indo-ks8-overview.pdf, 
Kemenristekdikti (2016). Kekuatan 50 institusi ilmiah Indonesia: Profil publikasi ilmiah terindeks Scopus [The strength of 50 Indonesian universities: Publication profile in Scopus indexed journals]. Jakarta, Indonesia: Direktorat Pengelolaan Kekayaan Intelektual, Direktorat Jenderal Penguatan Riset dan Pengembangan Kemristekdikti Indonesia.

McCarthy, J. \& Rustam, I. (2010). Review of social science capacity building support to Indonesia's knowledge sector. Jakarta, Indonesia: Ausaid, Retrieved from http://dfat.gov.au/ about-us/publications/Documents/indo-ks9socialscience.pdf

Mirahayuni, N. K. (2002). Investigating generic structure of English research articles: Writing strategy differences between English and Indonesian writers. TEFLIN Journal, 11(1), 22-57.

Nielsen, G. (2010). Comparative experiences of middle income countries. Jakarta, Indonesia: AusAID, Retrieved from (http://dfat.gov.au/about-us/publications/ Documents/indo-ks10-comparative-experience.pdf)

Nugroho, Y. P., Budiati \& Ruhanawati, S. (2016). Mengatasi hambatan penelitian di universitas (Overcoming research obstacles in universities). Retrieved from http://www.ksi-indonesia.org/files/1464160545\$1\$DYOBW\$.pdf

Olszewska, K. \& Lock, J. (2016). Examining success and sustainability of academic writing: A case study of two writing-group models. Canadian Journal of Higher Education, 46(4), 132-145.

Rifai, M. A. (2016). Pegangan gaya penulisan, penyuntingan dan penerbitan karya ilmah Indonesia [Guidelines for writing, editing and publishing Indonesian scientific papers]. Yogyakarta, Indonesia: Gadjah Mada Unversity Press.

Safnil (2003). The rethorical style of Indonesian research article introduction: A genre analysis study. Journal of Asia-Pacific Education Researcher, 12(1), 2762.

Swales, J. M. (2004). Research genre: Explorations and applications. Cambridge, England: Cambridge University Press. 


\section{Authors' Brief CV}

Safnil Arsyad is a professor in the English Education Study Program of Languages and Arts Department of Teacher Training and Education Faculty of Bengkulu University, Indonesia. His area of research interest includes discourse analysis of research articles and other academic discourses and English teaching and learning material design and use. Email: safnil@unib.ac.id

Bambang Kaswanti Purwo is a professor in Linguistics at Universitas Katolik Atma Jaya Jakarta, Indonesia. He has published widely in national and international journals on Linguistics and Applied Linguistics. He can be contacted via email: bkaswanti@atmajaya.ac.id

Katharina Endriati Sukamto is an associate professor in Linguistics at Universitas Katolik Atma Jaya Jakarta, Indonesia. She has published widely in national and international journals on Linguistics. She can be contacted via email: katharina.sukamto@gmail.com

Zifirdaus Adnan is an associate professor in Applied Linguistics at University of New England Armidale New South Wales Australia. He has published widely in indexed or reputable international journals on Applied Linguistics and Language Education. He can be contacted via email: zadnan@une.edu.au

Appendix 1: Questionnaire

\section{QUESTIONNAIRE}

\section{PROBLEMS IN REPUTABLE/INDEXED INTERNATIONAL JOURNAL PUBLICATION BY LECTURERS AND/OR RESEARCHERS}

No:

This questionnaire is intended to find out the main reasons why many university lecturers in linguistics and language education have never or have not succeeded in publishing the results of their research in reputable/indexed international journals. This study aims to help improve the publication of Indonesian scholars which is still very alarming compared to other smaller countries so that the government will make it a national priority. We are very grateful for your willingness to fill in this questionnaire with factual information. We promise to maintain the confidentiality of the information that you provide through this questionnaire. 
Safnil Arsyad, Bambang Kuswanti Purwo, Katharina Endriati Sukamto, Zifirdaus Adnan

\section{Directions}

- Mark the appropriate answer for each item! and/or

- Fill in the answers in the space provided!

\section{A. Respondent identities}

1. Qualification $: \quad$ S2 $\quad$ S3

2. The number of research projects ever conducted:

3. How long have you been a lecturer year $/ \mathrm{s}$

4. Rank of lectureship

\section{B. General questions}

1. Have you ever received research funding from the central government (Kemristekdikti) or from other sources that is sufficient to prepare articles to be submitted to reputable international journals, for example above 100 million rupiah?
a. yes
b. no

2. Have you ever published an article in local or national journals?
a. yes
b. no
If yes, please mention the journal/s below!

3. Have you ever published in a national accredited journal?
a. yes
b. no

4. Have you ever published in reputable international journal/s?
a. yes
b. no
If yes, please mention the journal/s below!

5. If no, are you now repairing manuscript to be submitted to a reputable or indexed international journal?
a. yes
b. no

6. If no, are you willing to publish your article/s in international journals indexed in Scopus, DOAJ, Google Scholar, Web of Science etc.?
a. yes
b. maybe
c. no

7. If yes in which journal and indexed in what? 
Safnil Arsyad, Bambang Kuswanti Purwo, Katharina Endriati Sukamto, Zifirdaus Adnan

\section{Reasons for not publishing in reputable international journals}

8. If you answer 'no' in question number 5 , there are several reasons that can be a barrier for you to publish in international journals. Choose one of the values available for each answer (a factor that prevents you from publishing in international journals). Figures 1-5 indicate the level of reasons that hinder it.

1. Do not hinder

2. Hinder a little bit

3. Hinder enough

4. Hinder very much

5. The hindering factor is not significant

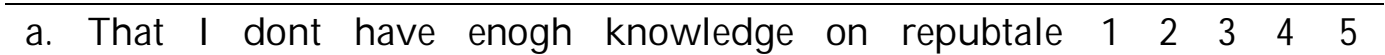
international journals, for me ...

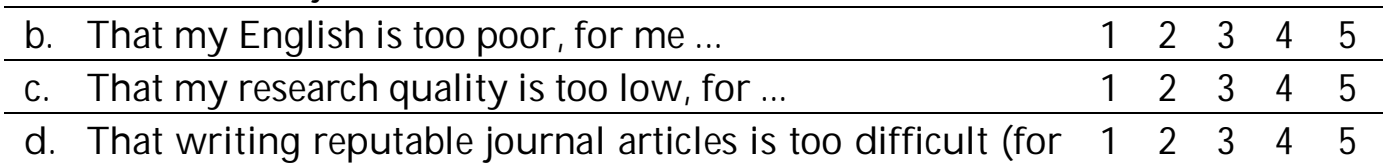
example, because there are many requirements that must be met), for me ...

e. That I dont know about the format of international $1120 \begin{array}{llll}2 & 2 & 4 & 5\end{array}$ journal article, for me ...

f. That international references are less available at the $\begin{array}{llllll}1 & 2 & 3 & 4 & 5\end{array}$ faculty and /or university, for me ...

g. That there is no financial help for writing articles for $\begin{array}{llllll}1 & 2 & 3 & 4 & 5\end{array}$ international journal publications, for me ...

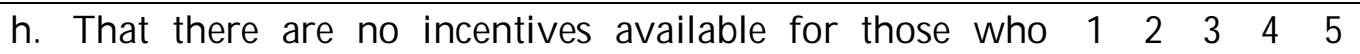
publish in reputable international journals, for me ...

i. Mention other reasons for not publishing in reputable $1 \begin{array}{llllll}1 & 2 & 3 & 4 & 5\end{array}$ international journals (if any) and mark the level of the reason hindering it

\section{Attitude towards reputable international journal publication}

9. How is your attitude towards having to publish in reputable/nndexed international journals? Mark one of the choices a, b, c, d, or e to show your attitude!

a. I would like to publish my research results in reputable international journals but I do not have time to fulfill the requirements because there are too many other more urgent tasks such as teaching, administrative tasks, community service and other campus assignments. 

a. Strongly disagree
b. Disagree
c. Neutral
d. Agree
e. Strongly agree

b. Actually I would be very happy if I could publish the results of my research in reputable/indexed international journals, but I was unable to fulfill the requirements. If anyone helps, I will definitely try hard for that.
a. Strongly disagree
b. Disagree
c. Neutral
d. Agree
e. Strongly agree

10. Choose one of the values available for each answer (a factor that prevents you from publishing in international journals). Figures 1-5 show the seriousness of the obstacles of the related factors.

1. Do not hinder

2. Hinder a little bit

3. Hinder enough

4. Hinder very much

5. The hindering factor is not significant

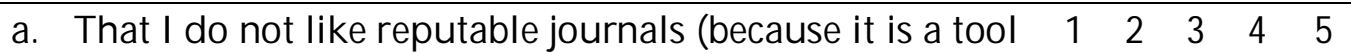
of Western countries to control other countries or a new form of colonialism), for me ...

b. That I am not confident about the results of my $11220 \begin{array}{lllll} & 2 & 3 & 4 & 5\end{array}$ research to be accepted in reputable journals because the quality is not in line with those by international authors, for me ...

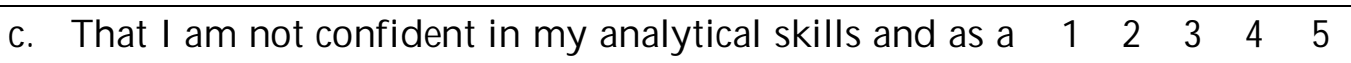
result my research results do not meet the criteria of a reputable international journal, for me.

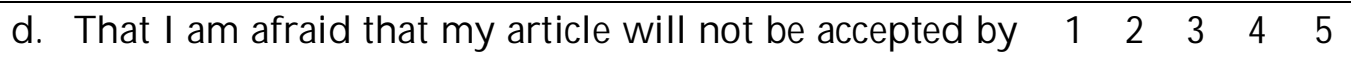
'editors' or 'reviewers' of international journals, for me

e. That I am not interested in reputable international $1120 \begin{array}{lllll} & 2 & 3 & 4 & 5\end{array}$ journals, because it is financially unattractive while the demands are high, especially the rewards are not only difficult but also not certain to be obtained; while, I need money to meet family needs, for me ...

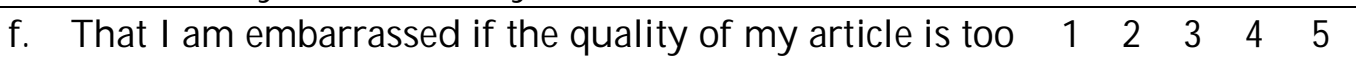
low, for me ... 
Safnil Arsyad, Bambang Kuswanti Purwo, Katharina Endriati Sukamto, Zifirdaus Adnan

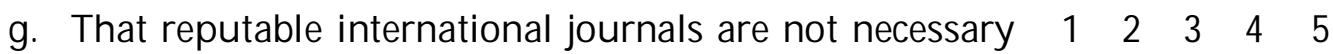
because they only trouble us and an accredited national journal is enough, for me ...

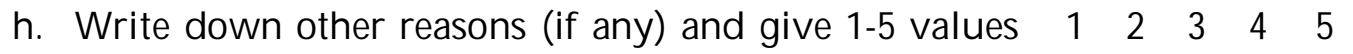
for each of those reasons...

\section{E. Necessary efforts to publish in reputable international journals}

11. The following are eight or more activities that can be done in an effort to prepare yourselves to be able to write articles that qualify for publication in reputable/indexed international journals. According to you, how effective is each activity to prepare yourself? Figures 1-5 show the effectiveness of the activity.

1. Not effective

2. A little bit effective

3. Effective enough

4. Very effective but not determining

5. Most effective

\begin{tabular}{|c|c|c|c|c|c|}
\hline a. Improving English ability & 1 & 2 & 3 & 4 & 5 \\
\hline $\begin{array}{l}\text { b. Studying the format and style of writing research } \\
\text { articles in international journals (among others, } \\
\text { through scientific writing manuals) }\end{array}$ & 1 & 2 & 3 & 4 & 5 \\
\hline $\begin{array}{l}\text { c. Writing articles in Indonesian and then asking a } \\
\text { translator to translate it into English }\end{array}$ & 1 & 2 & 3 & 4 & 5 \\
\hline $\begin{array}{l}\text { d. Reading research articles published in international } \\
\text { journals as many as possible }\end{array}$ & 1 & 2 & 3 & 4 & 5 \\
\hline $\begin{array}{l}\text { e. Trying to be confident to send each research article } \\
\text { to an international journal (although not necessarily } \\
\text { accepted) }\end{array}$ & 1 & 2 & 3 & 4 & 5 \\
\hline $\begin{array}{l}\text { f. Frequently writing articles (although in Indonesian) } \\
\text { to be published in national accreditted journals }\end{array}$ & 1 & 2 & 3 & 4 & 5 \\
\hline $\begin{array}{l}\text { g. Frequently attending workshop on reputable } \\
\text { international journal publication }\end{array}$ & 1 & 2 & 3 & 4 & 5 \\
\hline $\begin{array}{l}\text { h. Asking for accompany to a researcher who has been } \\
\text { successful in reputable international journal } \\
\text { publication }\end{array}$ & 1 & 2 & 3 & 4 & 5 \\
\hline $\begin{array}{l}\text { i. Write other activities (if any) and mark its } \\
\text { effectiveness! }\end{array}$ & 1 & 2 & 3 & 4 & 5 \\
\hline
\end{tabular}

Journal on English as a Foreign Language, 9(1), 42-70

Copyright @ 2019 by JEFL, p-ISSN 2088-1657; e-ISSN 2502-6615 
12. According to you, what efforts should be made by universities for all lecturers so that they can write articles that meet the general requirements of reputable international journals in the fields of language and language education? If your answer is more than one, give a value of 1-5 according to the level of effectiveness (such as in items number 11).

13. According to you, what should Kemenristekdikti do for all lecturers and researchers so that they can prepare articles that meet the general requirements of reputable international journals in their disciplines? If your answer is more than one, give a value of 1-5 according to the level of effectiveness (such as in items number 11)

\section{F. Advantages of publishing in reputable international journals}

14. According to you, what advantages can you get from publicshing in reputable international journals? Choose the answer below and mark the values available for each answer. Figures 1-5 indicate the level of influence of related or assessed factors.

1. Do not affect at all

2. Affect a little

3. Affect enough

4. Affect very much but not determining

5. Affect the most

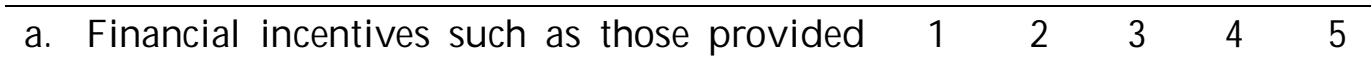
by institutions or Kemristekdikti

\begin{tabular}{lllllll}
\hline b. & Personal reputation & 1 & 2 & 3 & 4 & 5 \\
\hline c. & Self-satisfaction & 1 & 2 & 3 & 4 & 5 \\
\hline d. & Credit points for promotion & 1 & 2 & 3 & 4 & 5 \\
\hline e. & Institution reputation & 1 & 2 & 3 & 4 & 5 \\
\hline f. & Write down other benefits (if nay) and mark & 1 & 2 & 3 & 4 & 5
\end{tabular}
the 1-5 values for each of the other benefits.

Thank you for filling this questionnaire!

Journal on English as a Foreign Language, 9(1), 42-70

Copyright (C) 2019 by JEFL, p-ISSN 2088-1657; e-ISSN 2502-6615 
Safnil Arsyad, Bambang Kuswanti Purwo, Katharina Endriati Sukamto, Zifirdaus Adnan

\section{Appendix 2: Questions for the Interviews}

\section{LIST OF QUESTIONS FOR THE INTERVIEWS}

1. Do you have anything else to say about publications in reputable/indexed international journals for Indonesian lecturers or researchers which have not been included in the questionnaire?

2. How is the academic atmosphere in your university about publishing in reputable/indexed international journals?

3. Does the policy of the faculty and university leaders make you motivated to write articles for reputable/indexed international journals?

4. What is your own experience in writing articles to be published in reputable/ indexed international journals, either successful or unsuccessful experiences?

5. What will you do to successfully publish in reputable/indexed international journals?

6. Why do you think that publications of Indonesian lecturers or researchers in reputable/indexed international journals are below our neighboring countries like Malaysia and Singapore?

7. What is your suggestion for your fellow lecturers or other researchers to successfully publish in reputable/indexed international journals?

8. What is your suggestion to faculty and/or university leaders so that lecturers are eager to write articles to be published in reputable/indexed international journals? 